\title{
The Analysis of Transverse Topographic Symmetry Factor (T Index) in the Chekene-Mazavand, North East Iran
}

\author{
Mohammad Reza Sajadian1, Mohsen Pourkermani1 ${ }^{*}$, Manochehr Qorashi1, \\ Naser Hafezi Moghaddas ${ }^{2}$ \\ ${ }^{1}$ Department of Geology, North Branch, Islamic Azad University, Tehran, Iran \\ ${ }^{2}$ Department of Geology, Ferdowsi University, Mashhad, Iran \\ Email: "mohsen.poukermani@gmail.com
}

Received 12 September 2015; accepted 24 November 2015; published 30 November 2015

Copyright (C) 2015 by authors and Scientific Research Publishing Inc.

This work is licensed under the Creative Commons Attribution International License (CC BY). http://creativecommons.org/licenses/by/4.0/

\section{(c) (i) Open Access}

\begin{abstract}
T index has been calculated in the Chekene-Mazavand region in the NE Iran. This index shows lateral tilting may be related to active tectonics. There are many streams and transverse topographic symmetry factor has been calculated for all streams of Kashafroud river. Firstly, based on digital elevation model, the study area was divided into 28 sub-basins. Then transverse topographic symmetry factor was calculated for each one. The values are between 0.14 and 0.57 and so, there are low, moderate and high levels of relative tectonic activities. The areas with low relative tectonic activities have found in sub-basins No. 14, 15 and 24, moderate relative tectonic activities have found in sub-basins No. 2, 5, 6, 7, 9, 10, 13, 16, 18, 19, 21, 22, 23, 25, 27 and 28 and high relative tectonic activities have found in sub-basins No. 1, 3, 4, 8, 11, 12, 17, 20 and 26. The results show that the plains have got low to moderate level of tectonic activity and faulted areas have got high tectonic activity. This matter is compatible with its tectonic setting on the Kopet Dagh belt in north east Iran.
\end{abstract}

\section{Keywords}

Transverse Topographic, Symmetry Factor, Chekene-Mazavand, Tectonic, Iran

\section{Introduction}

The Chekene-Mazavand area is located in the Kopet Dagh physiographic province, NE Iran (Figure 1). Dominant structural trend in Kopet Dagh province is NW-SE. From tectonics view, it contains the Kopet Dagh

"Corresponding author.

How to cite this paper: Sajadian, M.R., Pourkermani, M., Qorashi, M. and Moghaddas, N.H. (2015) The Analysis of Transverse Topographic Symmetry Factor (T index) in the Chekene-Mazavand, North East Iran. Open Journal of Geology, 5, 809-820. http://dx.doi.org/10.4236/ojg.2015.511069 


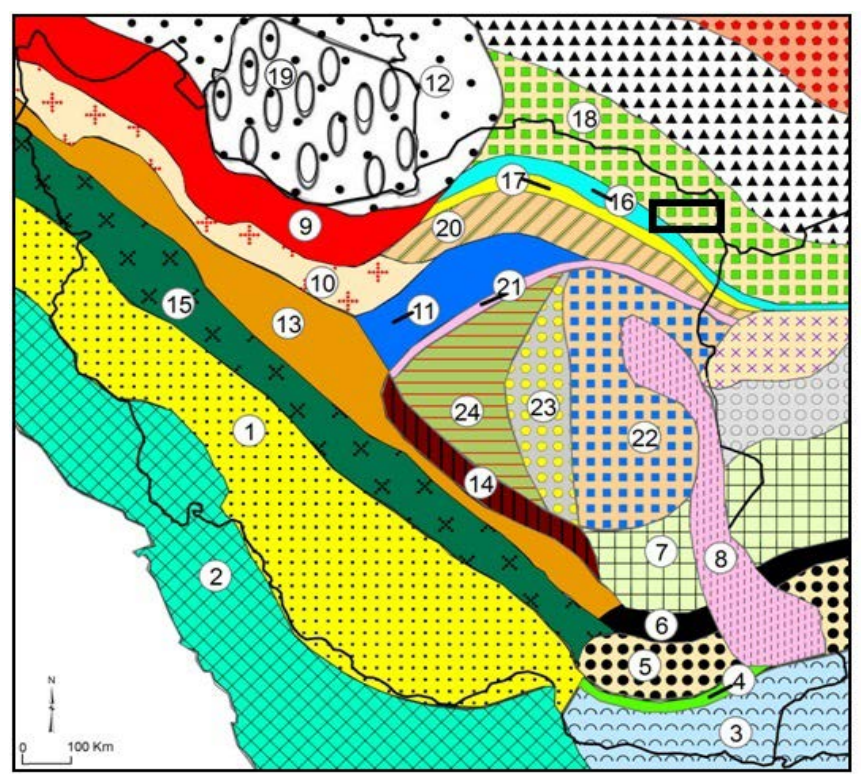

\begin{abstract}
Figure 1. Physiographic-tectonic zoning map of Iran's sedimentary basins, modified from [1]. Numbers in this figure are: 1: Zagros-East Taurus hinterland, 2: Persian GulfMesopotamian foreland basin, 3: Makran accretionary prism, 4: Bashagard Mountains, 5: Jazmorian-Mashkel fore arc basin, 6: Shahsavaran-Soltan magmatic arc, 7: South LutSouth Helmand back arc basin, 8: East Iran Mountain belt, 9: West-Central Alborz and lesser Caucasus hinterland, 10: Great Kavir-Northen Urmieh lake foreland basin, 11: South Great Kavirfold and thrust belt, 12: South Caspian-Black sea foreland basin, 13: Urmieh-Dokhtar Magmatic Arc, 14: Naien-Kerman retro arc foreland basin, 15: Sanandaj-Sirjanoverthrust belts, 16: East Alborz or Binalod hinterland, 17: Torbat-e am-Neyshabour retro arc foreland basin, 18: Kopet Dagh hinterland, 19: South Caspian remnant basin, 20: Maiamay-Taibad Inverted back arc basin, 21: Khaf-Kavir Plain Magmatic Arc, 22: Lut Plain-Gonabad back arc basin, 23: Tabas hinterland, 24: Yazd-Khour Piggy back basin. The study area is shown in the black rectangle.
\end{abstract}

hinterland or Kopet Dagh fold and thrust belt that formed in passive margin of Eurasian plate until late Triassic and then marine sedimentation on Kopet Dagh proforeland basin has continued to Eocene. Kopet Dagh hinterland has uplifted related to Karakorum foreland basin in north east along Eshghabad fault [1]-[3].

Based on previous work on the salt and mud diapirism [4]-[15] and neotectonic regime in Iran [16]-[21], Zagros in south Iran is the most active zone [22]-[44]. Then, Alborz [45]-[84] and Central Iran [85]-[100] have been situated in the next orders. The analysis of $\mathrm{T}$ index that shows lateral tilting is the main goal in this paper.

\title{
2. Materials and Methods
}

The transverse topographic symmetry factor shows lateral tilting that it may be related to active tectonics. There are many streams and transverse topographic symmetry factor has been calculated for all streams of Kashafroud river (Figure 2 and Figure 3). Kashafroud river is the main river in the Chekene-Mazavand area (Figure 4). Based on digital elevation model of Chekene-Mazavand area, there are 28 sub-basins. The study area is located between longitudes $\mathrm{E} 58^{\circ}, 30^{\prime}-61^{\circ}$ and latitudes N35, $30^{\prime}-37^{\circ}$ in the Khorasan province, in the NE Iran.

\section{Transverse Topographic Symmetry Factor (T)}

$\mathrm{T}$ index or transverse topographic symmetry factor has been calculated as $\mathrm{T}=\mathrm{Da} / \mathrm{Dd}$ and it can be between 0 in the symmetric basin and 1 in the asymmetry basin.

$\mathrm{Da}$ is the space from the midline of the drainage basin to the midline of the active belt and Dd is the space from the midline to the basin limit [101]. In this research, we were considered class 1 for $T>0.4$, class 2 for $\mathrm{T}$ between 0.2 and 0.4 and class 3 for $\mathrm{T}<0.2$ and so, sub-basin No. 1, 3, 4, 8, 11, 12, 17, 20 and 26 shows higher activity (Table 1). 


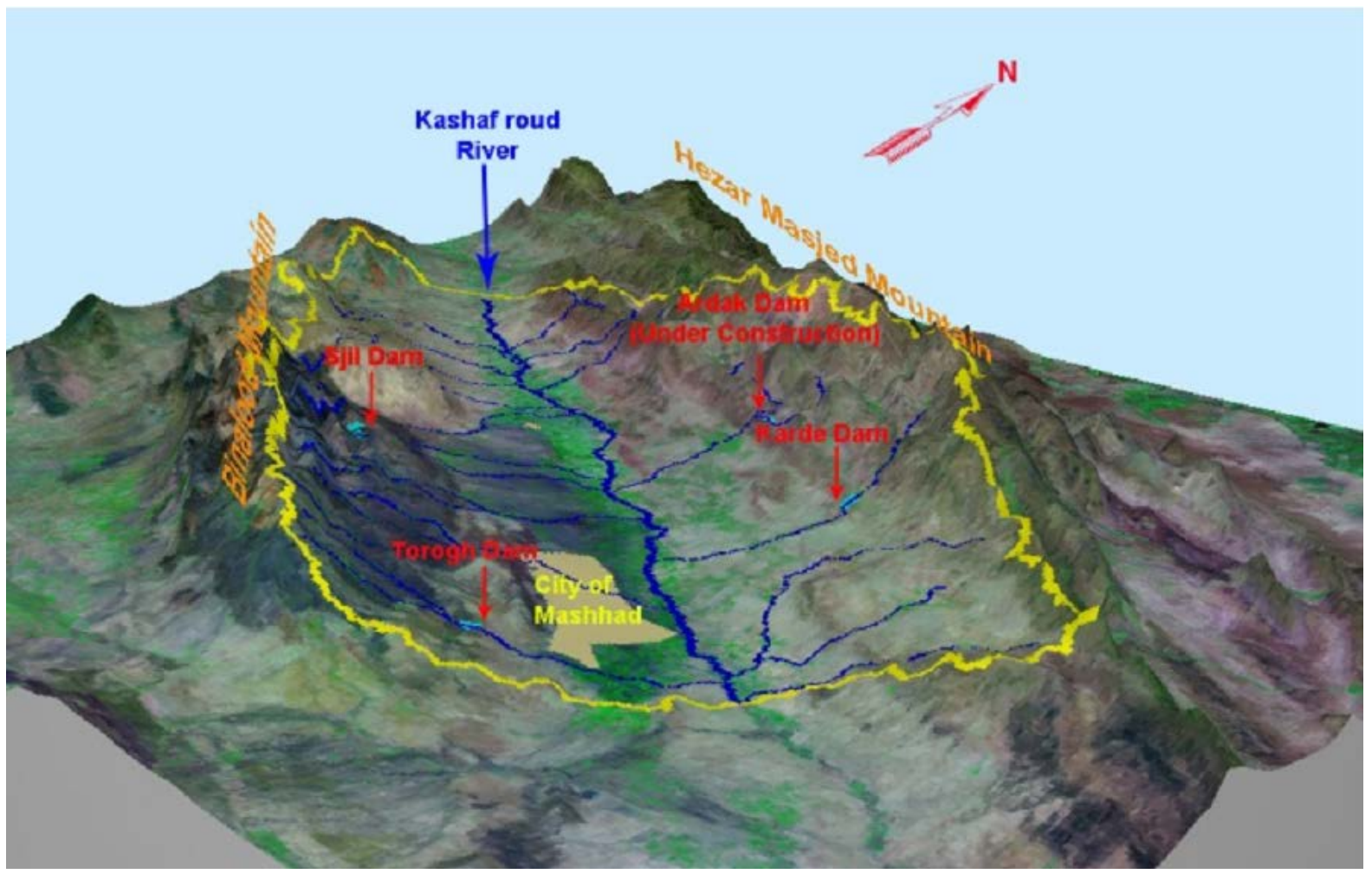

Figure 2. An oblique view on Landsat satellite image that shows some streams of the Kashafroud river.

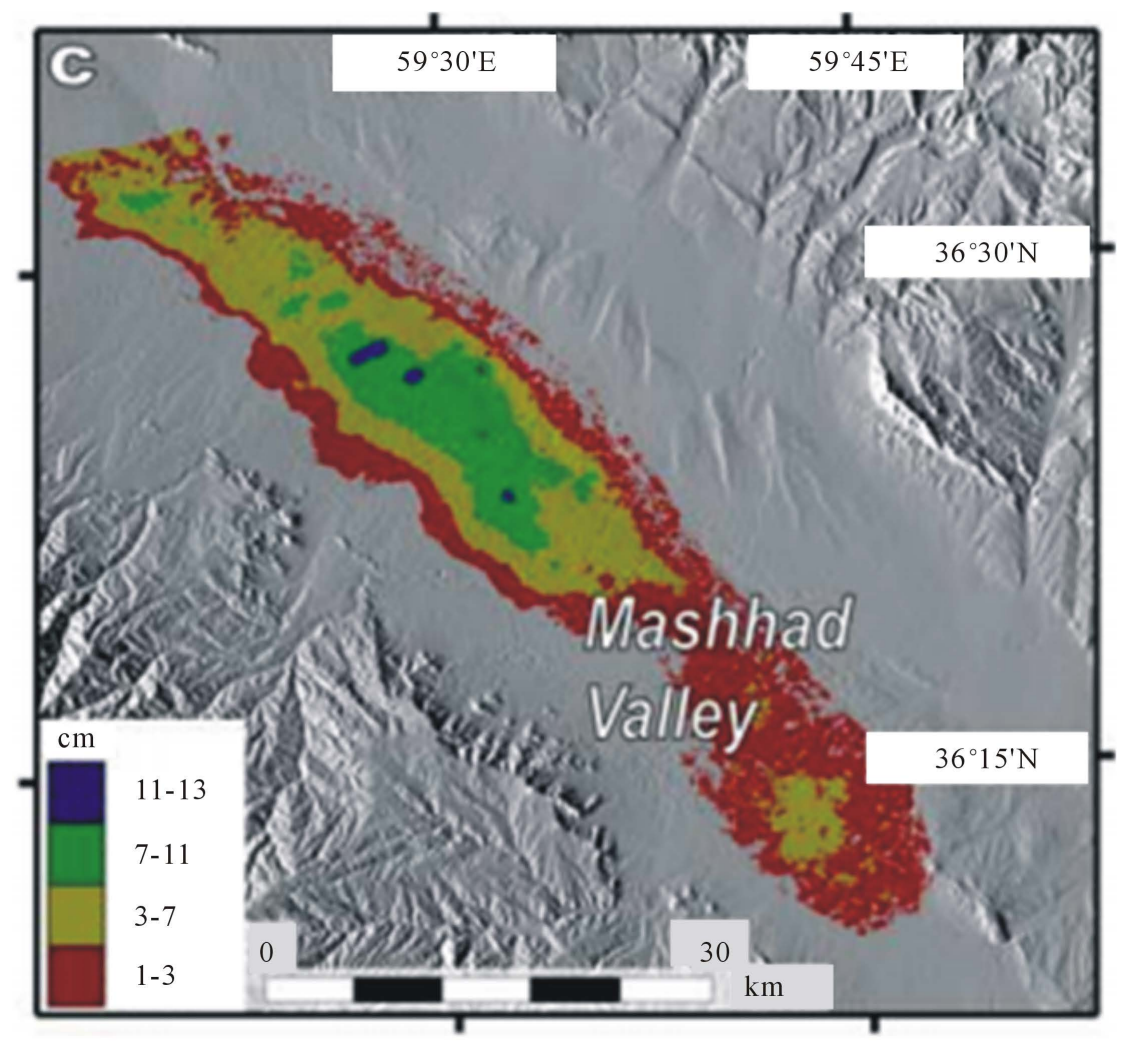

Figure 3. Land subsidence value around the middle part of Kashafroud river plain. 


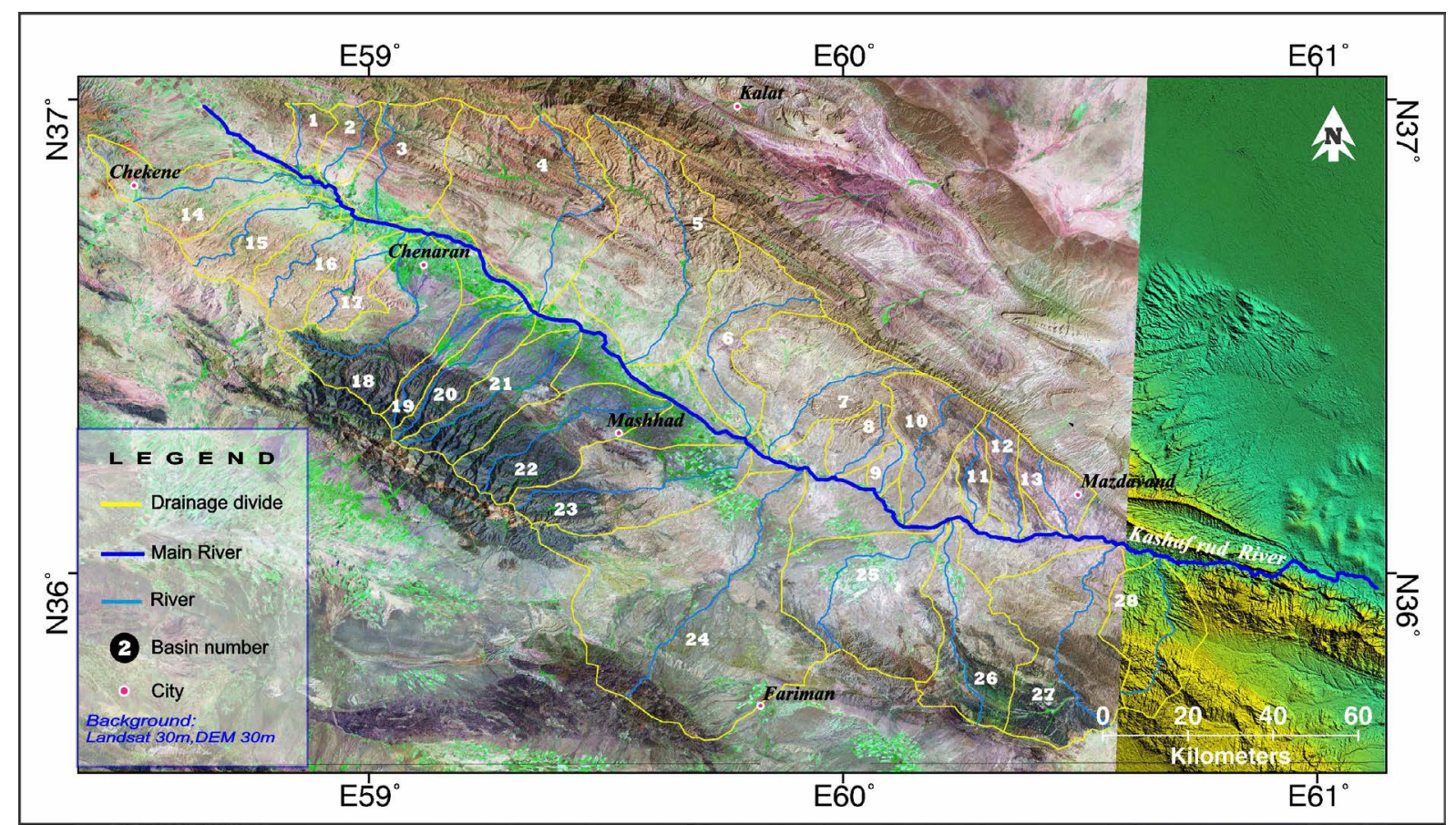

Figure 4. The sub-basins on Landsat satellite image of the Chekene-Mazavand area.

Table 1. Values of $\mathrm{T}$ index for sub-basins.

\begin{tabular}{|c|c|c|c|c|c|c|}
\hline \multicolumn{7}{|c|}{$T$ index } \\
\hline Sub-basin & Number & Da (m) & Dd (m) & $\mathbf{T}(\mathrm{m})$ & $\mathbf{T}_{\text {ave }}(\mathrm{m})$ & Class \\
\hline \multirow{2}{*}{1} & 1 & 2270 & 3589 & 0.63 & \multirow{2}{*}{0.52} & \multirow{2}{*}{1} \\
\hline & 2 & 1289 & 3179 & 0.41 & & \\
\hline \multirow{4}{*}{2} & 1 & 299 & 5520 & 0.05 & \multirow{4}{*}{0.31} & \multirow{4}{*}{2} \\
\hline & 2 & 1172 & 3405 & 0.34 & & \\
\hline & 3 & 1543 & 4602 & 0.34 & & \\
\hline & 4 & 1956 & 3860 & 0.51 & & \\
\hline \multirow{3}{*}{3} & 1 & 4386 & 7830 & 0.56 & \multirow{3}{*}{0.57} & \multirow{3}{*}{1} \\
\hline & 2 & 6280 & 7480 & 0.84 & & \\
\hline & 3 & 2178 & 7200 & 0.30 & & \\
\hline \multirow{3}{*}{4} & 1 & 8530 & 11010 & 0.77 & \multirow{3}{*}{0.53} & \multirow{3}{*}{1} \\
\hline & 2 & 10920 & 14770 & 0.74 & & \\
\hline & 3 & 427 & 5280 & 0.08 & & \\
\hline \multirow{5}{*}{5} & 1 & 3091 & 11440 & 0.27 & \multirow{5}{*}{0.34} & \multirow{5}{*}{2} \\
\hline & 2 & 1602 & 10110 & 0.16 & & \\
\hline & 3 & 3082 & 12290 & 0.25 & & \\
\hline & 4 & 5010 & 11210 & 0.45 & & \\
\hline & 5 & 6810 & 12200 & 0.56 & & \\
\hline \multirow{5}{*}{6} & 1 & 5850 & 10600 & 0.55 & \multirow{5}{*}{0.29} & \multirow{5}{*}{2} \\
\hline & 2 & 1099 & 6900 & 0.16 & & \\
\hline & 3 & 1940 & 4170 & 0.47 & & \\
\hline & 4 & 345 & 6200 & 0.06 & & \\
\hline & 5 & 1478 & 7240 & 0.20 & & \\
\hline
\end{tabular}




\section{Continued}

\begin{tabular}{|c|c|c|c|c|c|c|}
\hline \multirow{4}{*}{7} & 1 & 6140 & 16330 & 0.38 & \multirow{4}{*}{0.38} & \multirow{4}{*}{2} \\
\hline & 2 & 2694 & 10680 & 0.25 & & \\
\hline & 3 & 2266 & 5680 & 0.40 & & \\
\hline & 4 & 401.6 & 1737 & 0.23 & & \\
\hline \multirow{3}{*}{8} & 1 & 2797 & 6010 & 0.47 & \multirow{3}{*}{0.48} & \multirow{3}{*}{1} \\
\hline & 2 & 2578 & 5270 & 0.49 & & \\
\hline & 1 & 852.6 & 1939 & 0.44 & & \\
\hline \multirow[t]{3}{*}{9} & 2 & 120.7 & 2851 & 0.04 & \multirow[t]{3}{*}{0.34} & \multirow[t]{3}{*}{2} \\
\hline & 3 & 943.7 & 1771 & 0.53 & & \\
\hline & 1 & 2702 & 8260 & 0.33 & & \\
\hline \multirow[t]{4}{*}{10} & 2 & 1840 & 9650 & 0.19 & \multirow[t]{2}{*}{0.31} & \multirow[t]{2}{*}{2} \\
\hline & 3 & 1601 & 3840 & 0.42 & & \\
\hline & 1 & 1433 & 3551 & 0.40 & & \\
\hline & 2 & 2227 & 3833 & 0.58 & \multirow{4}{*}{0.48} & \multirow{3}{*}{1} \\
\hline \multirow{3}{*}{11} & 3 & 1646 & 3238 & 0.51 & & \\
\hline & 4 & 608 & 1459 & 0.42 & & \\
\hline & 1 & 2822 & 5170 & 0.55 & & \\
\hline \multirow[t]{3}{*}{12} & 2 & 1323 & 3062 & 0.43 & \multirow[t]{3}{*}{0.48} & \multirow[t]{3}{*}{1} \\
\hline & 3 & 1075 & 2322 & 0.46 & & \\
\hline & 1 & 706 & 6340 & 0.11 & & \\
\hline \multirow[t]{3}{*}{13} & 2 & 2349 & 5700 & 0.41 & \multirow[t]{3}{*}{0.27} & \multirow[t]{3}{*}{2} \\
\hline & 3 & 1142 & 4077 & 0.28 & & \\
\hline & 1 & 1850 & 5570 & 0.33 & & \\
\hline \multirow[t]{3}{*}{14} & 2 & 775 & 6600 & 0.12 & \multirow[t]{3}{*}{0.19} & \multirow[t]{3}{*}{3} \\
\hline & 3 & 730 & 5760 & 0.13 & & \\
\hline & 1 & 512 & 5570 & 0.09 & & \\
\hline \multirow[t]{3}{*}{15} & 2 & 743 & 6950 & 0.11 & 0.14 & 3 \\
\hline & 3 & 1275 & 5940 & 0.21 & & \\
\hline & 1 & 3315 & 7790 & 0.43 & & \\
\hline 16 & 2 & 2615 & 6690 & 0.39 & 7 & ? \\
\hline 10 & 3 & 417 & 6610 & 0.06 & 0.27 & 2 \\
\hline & 4 & 849 & 4575 & 0.19 & & \\
\hline & 1 & 1101 & 5730 & 0.19 & & \\
\hline 17 & 2 & 4113 & 7320 & 0.56 & 0.41 & 1 \\
\hline & 3 & 2491 & 3564 & 0.70 & & \\
\hline & 4 & 359 & 1860 & 0.19 & & \\
\hline & 1 & 6620 & 14130 & 0.47 & & \\
\hline & 2 & 1554 & 7490 & 0.21 & & \\
\hline 18 & 3 & 1158 & 7120 & 0.16 & 0.25 & 2 \\
\hline & 4 & 821 & 7410 & 0.11 & & \\
\hline & 5 & 1296 & 4619 & 0.28 & & \\
\hline
\end{tabular}


M. R. Sajadian et al.

\section{Continued}

\begin{tabular}{|c|c|c|c|c|c|c|}
\hline & 1 & 417 & 2146 & 0.19 & \multirow{5}{*}{0.31} & \multirow{5}{*}{2} \\
\hline & 2 & 2165 & 3330 & 0.65 & & \\
\hline \multirow[t]{4}{*}{19} & 3 & 558 & 2318 & 0.24 & & \\
\hline & 4 & 227 & 2718 & 0.08 & & \\
\hline & 5 & 947 & 2493 & 0.38 & & \\
\hline & 1 & 336 & 2239 & 0.15 & \multirow{3}{*}{0.45} & \multirow{3}{*}{1} \\
\hline \multirow[t]{3}{*}{20} & 2 & 2907 & 4464 & 0.65 & & \\
\hline & 3 & 2094 & 3748 & 0.56 & & \\
\hline & 1 & 2645 & 5780 & 0.46 & \multirow{4}{*}{0.25} & \multirow{4}{*}{2} \\
\hline \multirow{3}{*}{21} & 2 & 1055 & 5930 & 0.18 & & \\
\hline & 3 & 1957 & 7620 & 0.26 & & \\
\hline & 4 & 501 & 4000 & 0.13 & & \\
\hline \multirow{5}{*}{22} & 1 & 936.7 & 6440 & 0.15 & \multirow{5}{*}{0.20} & \multirow{5}{*}{2} \\
\hline & 2 & 2366 & 6510 & 0.36 & & \\
\hline & 3 & 1222 & 8630 & 0.14 & & \\
\hline & 4 & 787 & 6040 & 0.13 & & \\
\hline & 5 & 1035 & 5060 & 0.20 & & \\
\hline \multirow{4}{*}{23} & 1 & 1896 & 5600 & 0.34 & \multirow{4}{*}{0.28} & \multirow{4}{*}{2} \\
\hline & 2 & 1635 & 11490 & 0.14 & & \\
\hline & 3 & 2476 & 9070 & 0.27 & & \\
\hline & 4 & 1510 & 4137 & 0.36 & & \\
\hline \multirow{5}{*}{24} & 1 & 2887 & 22910 & 0.13 & \multirow{5}{*}{0.18} & \multirow{5}{*}{3} \\
\hline & 2 & 4287 & 30250 & 0.14 & & \\
\hline & 3 & 4285 & 30830 & 0.14 & & \\
\hline & 4 & 2673 & 10240 & 0.26 & & \\
\hline & 5 & 1600 & 7570 & 0.21 & & \\
\hline \multirow{4}{*}{25} & 1 & 7970 & 15910 & 0.50 & \multirow{4}{*}{0.36} & \multirow{4}{*}{2} \\
\hline & 2 & 8440 & 18900 & 0.45 & & \\
\hline & 3 & 989 & 6560 & 0.15 & & \\
\hline & 4 & 528 & 1587 & 0.33 & & \\
\hline \multirow{4}{*}{26} & 1 & 2813 & 8350 & 0.34 & \multirow{4}{*}{0.44} & \multirow{4}{*}{1} \\
\hline & 2 & 6900 & 9720 & 0.71 & & \\
\hline & 3 & 1809 & 7480 & 0.24 & & \\
\hline & 4 & 1291 & 2660 & 0.49 & & \\
\hline \multirow{4}{*}{27} & 1 & 2333 & 9540 & 0.24 & & \\
\hline & 2 & 3596 & 10860 & 0.33 & & \\
\hline & 3 & 6210 & 9830 & 0.63 & 0.36 & 2 \\
\hline & 4 & 1330 & 6060 & 0.22 & & \\
\hline & 1 & 3609 & 5470 & 0.66 & & \\
\hline 28 & 2 & 1082 & 7250 & 0.15 & 0.35 & 2 \\
\hline & 3 & 3275 & 10000 & 0.33 & & \\
\hline & 4 & 1373 & 5510 & 0.25 & & \\
\hline
\end{tabular}




\section{Results and Discussion}

Our results show that Mashhad plain have got serious land subsidence which it was documented by field observations (Figures 5-7). Also, there are three levels of active tectonics. Low relative tectonic activities in sub-basins No. 14, 15 and 24, moderate relative tectonic activities in sub-basins No. 2, 5, 6, 7, 9, 10, 13, 16, 18, 19, 21, 22, 23, 25, 27 and 28 and finally high relative tectonic activities in sub-basins No. 1, 3, 4, 8, 11, 12, 17, 20 and 26. Also, the most parts of study area have shown moderate relative tectonic activities.

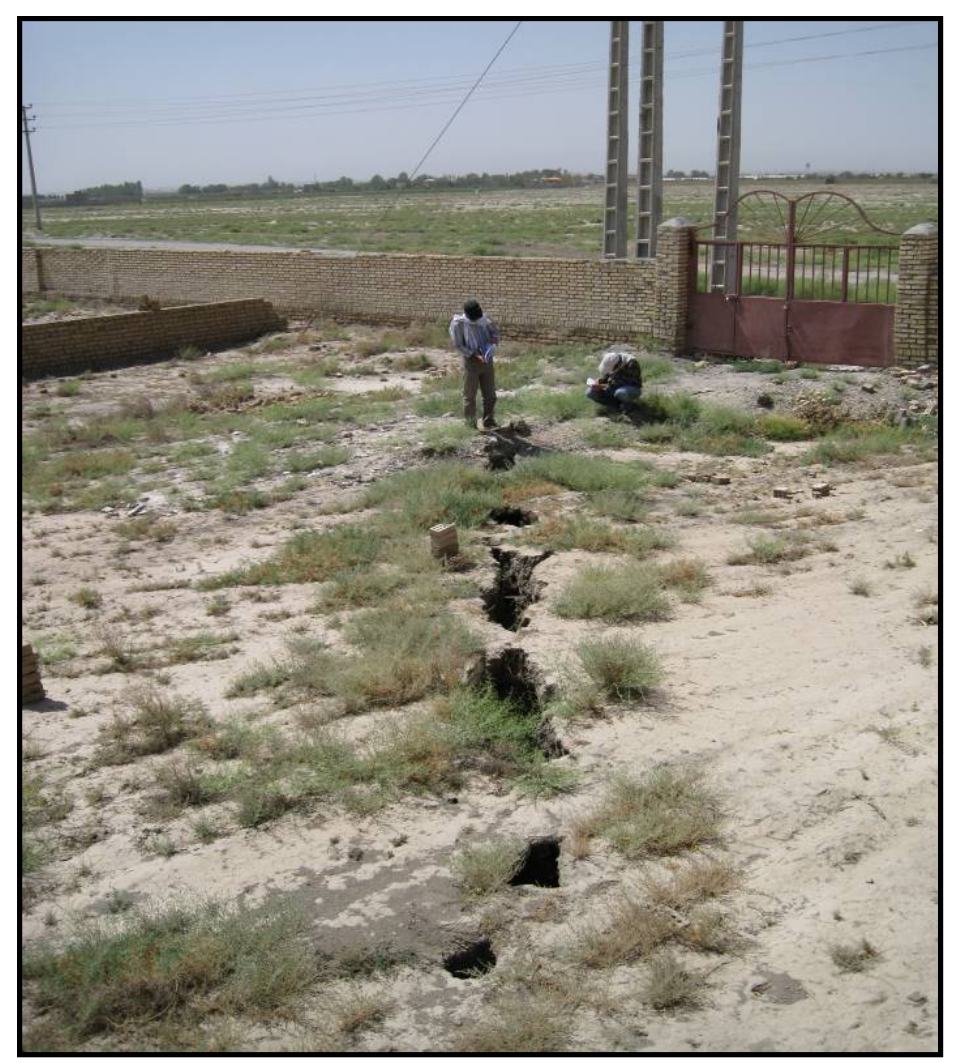

Figure 5. A view from cracks due to land subsidence in sub-basin No. 6.

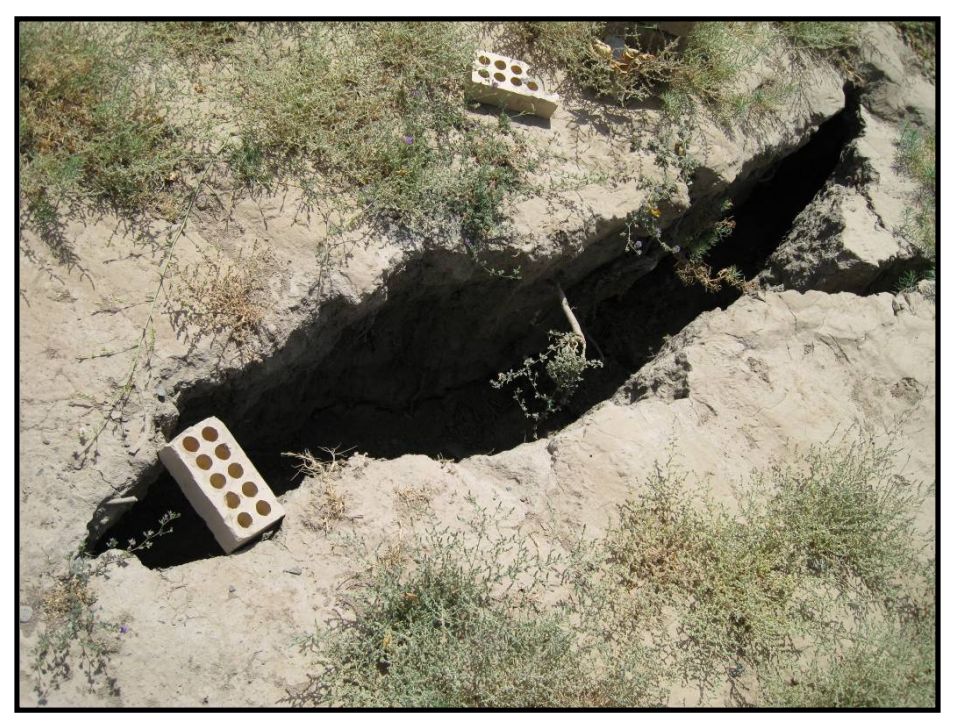

Figure 6. A close view from a crack in Figure 5. 


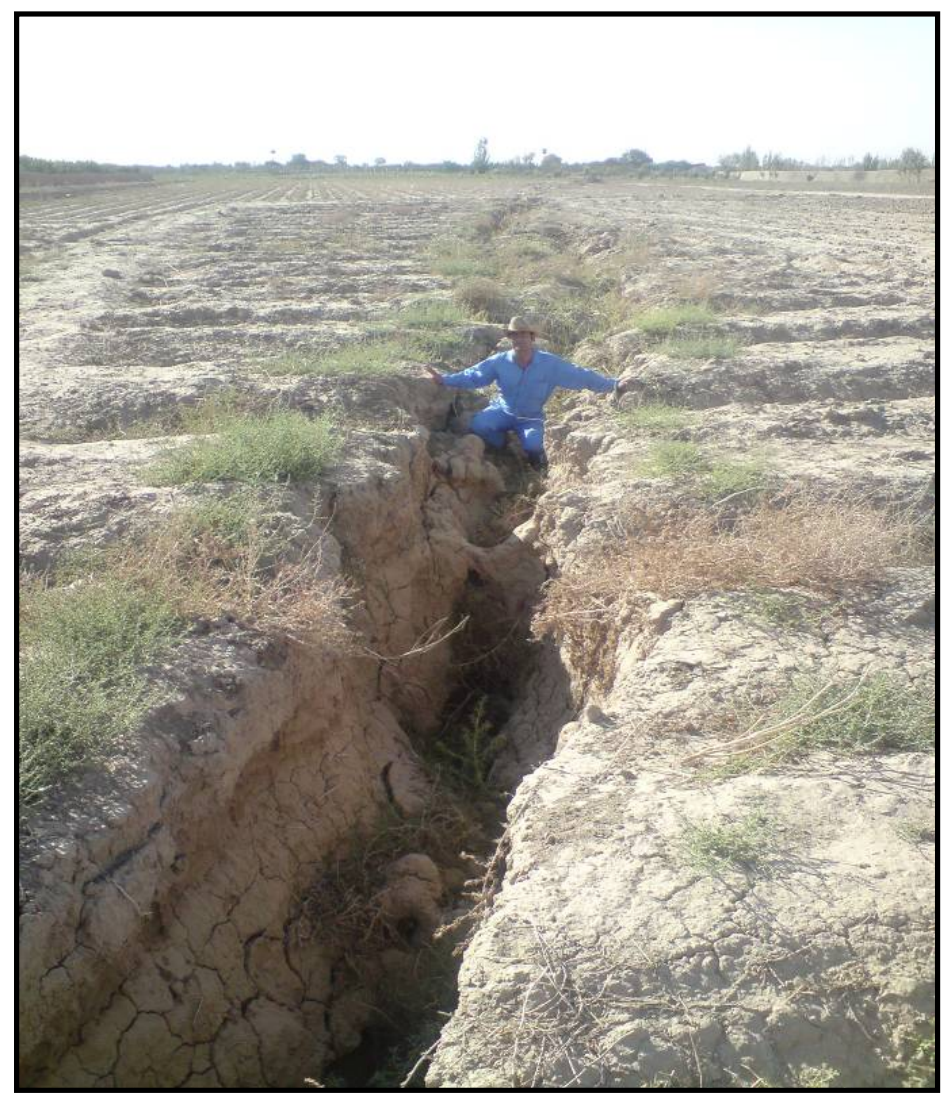

Figure 7. A view from a large crack which is related to land subsidence in sub-basin No.7.

\section{Conclusions}

In this research, the transverse topographic symmetry factor has been calculated in the Chekene-Mazavand area, north east Iran. Based on digital elevation model, the study area was divided into 28 sub-basins. Then transverse topographic symmetry factor was calculated for each one. The values of this index are between 0.14 and 0.57 , there are low, moderate and high levels of relative tectonic activities. The most parts of study area have shown moderate relative tectonic activities.

Low relative tectonic activities level has been found in sub-basins No. 14, 15 and 24, moderate relative tectonic activities level has been found in sub-basins No. 2, 5, 6, 7, 9, 10, 13, 16, 18, 19, 21, 22, 23, 25, 27 and high relative tectonic activities level has been found in sub-basins No. 1, 3, 4, 8, 11, 12, 17, 20 and 26. The latter cases are compatible with faulted parts of study area.

\section{Acknowledgements}

This work has funded by Department of Geology, Islamic Azad University, North Tehran Branch, Iran. Also, Special thanks to Dr. Mehran Arian and Dr. Elaheh Javadi Mosavi for their supports.

\section{References}

[1] Arian, M. (2013) Physiographic-Tectonic Zoning of Iran’s Sedimentary Basins. Open Journal of Geology, 3, $169-177$. http://dx.doi.org/10.4236/ojg.2013.33020

[2] Qorashi, M. and Arian, M. (2011) Tectonics of Iran. Geologic Survey of Iran, Tehran, 336 p.

[3] Arian, M. (2011) Basement Tectonics and Geology of Iran. Asar Nafis Press, Qum, 300 p.

[4] Arian, M. (2011) A Preface on Salt Diapirism of Iran. Asar Nafis Press, Qum, 309 p.

[5] Arian, M. and Noroozpour, H. (2015) The Biggest Salt-Tongue Canopy of Central Iran. Open Journal of Geology, 5, 
55-60. http://dx.doi.org/10.4236/ojg.2015.52005

[6] Asadian, F., Pourkermani, M. and Arian, M. (2007) Tectonic Geomorphology of Salt Structures in the GarmsarLasjerd Area. Geographical Research Quarterly, 39, 75-84.

[7] Pourkermani, M. and Arian, M. (1997) Salt Domes of Central Iran. Journal of Humanities, 3, 29-41.

[8] Arian, M. (2012) Salt Diapirism and Tectonics. 2nd Edition, Asar Nafis Press, Qum, 319 p.

[9] Arian, M. and Noroozpour, H. (2015) Tectonic Geomorphology of Iran's Salt Structures. Open Journal of Geology, 5, 61-72. http://dx.doi.org/10.4236/ojg.2015.52006

[10] Asadian, F. and Arian, M. (2009) Identification of Diapiric Provinces of Central Iran through Geological and Geographical Analysis. International Journal of Agriculture Environment \& Biotechnology, 2, 3443-3451.

[11] Arian, M. (2012) Clustering of Diapiric Provinces in the Central Iran Basin. Carbonates and Evaporites, 27, 9-18. http://dx.doi.org/10.1007/s13146-011-0079-9

[12] Pourkermani, M. and Arian, M. (1998) Tectonic Geomorphology of Salt Domes in West of Zanjan Province, Iran. Geographical Research, 47, 44-53.

[13] Arian, M. and Feizi, F. (2010) The Significance of Faulting on the Surficial Spreading of Evaporitic Deposits in the Varamin-Semnan Area. Journal of Earth and Resources, 3, 1-20.

[14] Feizi, F., Arian, M. and Arian, A. (2015) Mud Diapirism on the Makran, Iran: Case Study on the Napag Mud Volcano. Open Journal of Geology, 5, 300-308. http://dx.doi.org/10.4236/ojg.2015.55027

[15] Arian, M. and Sistanipour, A. (2015) Mud Diapirism on the Gorgan, North Iran. Open Journal of Geology, 5, $442-450$. http://dx.doi.org/10.4236/ojg.2015.56041

[16] Arian, M. and Khodabakhshnezhad, A. (2015) Sedimentary Environments Can Be Changed by Geotechnology (Case Study: A Morphotectonic Idea for Design of Extensive Artificial Bay on the Iranian Plateau). International Journal of Geosciences, 6, 487-496. http://dx.doi.org/10.4236/ijg.2015.65039

[17] Arian, M. (2011) Middle East Tectonics. Asar Nafis Press, Qum, 236 p.

[18] Arian, M. (2010) Applied Seismotectonics. Farazamin Press, Tehran, 304 p.

[19] Arian, M. and Maleki, R. (2008) Neotectonics. Farazamin Research Center, Tehran, 150 p.

[20] Pourkermani, M. and Arian, M. (1998) Seismicity of Iran. Shahid Beheshti University Press, Tehran, 212 p.

[21] Pourkermani, M. and Arian, M. (1997) Seismotectonics. Dez Ab Consulting Engineers Company Press, Tehran, 270 p.

[22] Arian, M. and Aram, Z. (2014) Relative Tectonic Activity Classification in the Kermanshah Area, Western Iran. Solid Earth, 5, 1277-1291. http://dx.doi.org/10.5194/se-5-1277-2014

[23] Mashal, M., PourKermani, M., Charchi, A., Almasian, M. and Arian, M. (2013) Pattern of Structural Geology Underground in Eastern of North Dezfol Embayment. Advances in Environmental Biology, 7, 260-268.

[24] Pazhoohan, M., Arian, M., Ghorashi, M. and Khosrotehrani, K. (2014) A Study of Drainage Pattern Responses to Active Tectonics in Tadvan Region, SW Iran. Geodynamics, 1, 36-41.

[25] Rahimi, N. and Arian, M. (2014) Tectonic Geomorphplogy of Kangavar-Sosangerd Region, West Iran. Advances in Environmental Biology, 8, 119-124.

[26] Arian, M. and Hashemi, A. (2008) Seismotectonic Zoning in the Zagros. Journal of Sciences, 18, 63-76.

[27] Arian, M., Ahmadnia, A., Qorashi, M. and Pourkermani, M. (2002) Structural Analysis of Mengharak Transcurrent Fault System in Zagros, Iran. Special Geo 2002 Conference Issue Geoarabia, 7, 209-210.

[28] Arian, M., Qorashi, M., Pourkermani, M. and Ahmadnia, A. (2003) Fractal Analysis of Mengharak Transcurrent Fault System in Zagros, Iran. Abstracts of 4th International Conference on Seismology and Earthquake Engineering, Tehran, 12-14 May 2003, 23.

[29] Baharvand, S., Pourkermani, M., Ajalloian, R., Arian, M. and Nouryazdan, A.R. (2010) Seymareh Landslide and Its Role in Environmental and Geomorphologic Changes of the Pole-Dokhtar Area. Journal of the Earth, 4, 13-24.

[30] Abdideh, M., Qorashi, M., Rangzan, K. and Arian, M. (2011) Assessment of Relative Active Tectonics Using Morphometric Analysis, Case Study of Dez River (Southwestern, Iran). Geosciences, 20, 33-46.

[31] Arian, M., Qorashi, M., Pourkermani, M. and Ahmadnia, A. (2006) The Structural Significance Kareh Bas Transcurrent Fault System in the Zagros Fold and Thrust Belt. Geosciences, 15, 126-133.

[32] Arian, M. and Noroozpour, H. (2015) Seismic Activity and Fractal Geometry of Kareh Bas Fault System in Zagros, South of Iran. Open Journal of Geology, 5, 291-299. http://dx.doi.org/10.4236/ojg.2015.55026

[33] Ehsani, J. and Arian, M. (2015) Quantitative Analysis of Relative Tectonic Activity in the Jarahi-Hendijan Basin Area, Zagros Iran. Geosciences Journal, 19, 1-15. http://dx.doi.org/10.1007/s12303-015-0016-3 
[34] Omidali, M., Arian, M. and Sorbi, A. (2015) Neotectonics of Boroujerd Area, SW Iran by Index of Active Tectonics. Open Journal of Geology, 5, 309-324. http://dx.doi.org/10.4236/ojg.2015.55028

[35] Chegini, A., Sorbi, A. and Arian, M. (2015) Active Tectonics of Hamedan Area, West Iran. International Journal of Geography and Geology, 4, 109-128.

[36] Maleki, Z., Arian, M., Solgi, A. and Ganjavian, M.A. (2014) The Elements of Fold Style Analysis in the Khaftar Anticline, Zagros, Iran. Open Journal of Geology, 4, 79-92. http://dx.doi.org/10.4236/ojg.2014.43008

[37] Maleki, Z., Arian, M. and Solgi, A. (2014) Structural Style and Hydrocarbon Trap of Karbasi Anticline, in the Interior Fars Region, Zagros, Iran. Solid Earth Discussions, 6, 2143-2167. http://dx.doi.org/10.5194/sed-6-2143-2014

[38] Ehsani, J., Arian, M. and Ghorashi, M. (2015) Geomorphic Signatures of Active Tectonics in the Jarahi-Hendijan Drainage Basin in the South West Iran. Geosciences, 24, 211-218.

[39] Khodabakhshnezhad, A., Pourkermani, M., Arian, M., Matkan, A.A. and Charchi, A. (2015) Active Tectonics of Great Karoun River Basin. Geosciences, 24, 13-28.

[40] Maleki, Z., Arian, M., Solgi, A. and Ganjavian, M.A. (2015) Elements of Fold Style Analysis in the Karbasi Anticline, Interior Fars Region, Zagros. Geosciences, 24, 293-302.

[41] Baratpour, F., Arian, M. and Solgi, A. (2015) Geometric Analysis of Tukak and Kamarun Anticlines on Izeh Zone, Zagros. Geosciences, 24, 191-200.

[42] Gholamhosein Fard, N., Sorbi, A. and Arian, M. (2015) Active Tectonics of Kangavar Area, West Iran. Open Journal of Geology, 5, 422-441. http://dx.doi.org/10.4236/ojg.2015.56040

[43] Maleki, Z., Arian, M. and Solgi, A. (2015) Folding Pattern in the Fars Province, Zagros Folded Belt: Case Study on the Karbasi and Khaftar Anticlines, Interior Fars, Iran. Solid Earth Discuss, 7, 2347-2379. http://dx.doi.org/10.5194/sed-7-2347-2015

[44] Razaghian, G. and Arian, M. (2015) The Emergent Salt Diapirs in the East Zagros, Iran. Open Journal of Geology, 5, 718-726. http://dx.doi.org/10.4236/ojg.2015.510063

[45] Alladin, Y., Talebian, M., Arian, M. and Ahmadi, M.M. (2015) Geotechnical Investigation and Seismic Zonation of Alluvial Deposits in Western Tehran. Geosciences, 24, 333-342.

[46] Taherkhani, B., Nazari, H., Pourkermani, M. and Arian, M. (2015) Geometry and Recent Kinematics of the North Qazvin Fault: Morphotectonic Approach. Geosciences, 24, 29-38.

[47] Manuchehri, H., Arian, M., Ghorashi, M., Solgi, M. and Sorbi, A. (2015) Geomorphic Signatures of Active Tectonics in the Chalus Drainage Basin in the Alborz, Iran. Geosciences, 24, 273-280.

[48] Noroozpour, H., Arian, M. and Sorbi, A. (2015) Fault Movement Potentials in the Tehran-Semnan Region (North Iran). Open Journal of Geology, 5, 281-290. http://dx.doi.org/10.4236/ojg.2015.55025

[49] Arian, M., Maleki, Z. and Noroozpour, H. (2011) Cenozoic Diastrophism and Deformational Events in the East Central Alborz. Journal of Basic and Applied Scientific Research, 1, 2394-2400.

[50] Feizi, F., Arian, A. and Rahmani, R. (2007) Seismotectonic Zoning in the Eastern Part of the Central Alborz. Journal of Sciences, 17, 151-164.

[51] Khavari, R., Arian, M. and Ghorashi, M. (2009) Neotectonics of the South Central Alborz Drainage Basin, in NW Tehran, N Iran. Journal of Applied Sciences, 9, 4115-4126. http://dx.doi.org/10.3923/jas.2009.4115.4126

[52] Arian, M. and Bagha, N. (2012) Active Tectonics of Tehran Area, Iran. Journal of Basic and Applied Scientific Research, 2, 3805-3819.

[53] Bagha, N., Arian, M., Ghorashi, M., Pourkermani, M., El Hamdouni, R. and Solgi, A. (2014) Evaluation of Relative Tectonic Activity in the Tehran Basin, Central Alborz, Northern Iran. Geomorphology, 213, 66-87. http://dx.doi.org/10.1016/j.geomorph.2013.12.041

[54] Arian, M. and Feizi, F. (2005) Application of Geomorphic Indices to the Assessment of Relative Tectonic Activity Levels in the Alborz-Central Iran Border Zone. Journal of Sciences, 15, 378-403.

[55] Arian, M., Bagha, N., Khavari, R. and Noroozpour, H. (2012) Seismic Sources and Neo-Tectonics of Tehran Area (North Iran). Indian Journal of Science and Technology, 5, 2379-2383.

[56] Moghimi, H., Arian, M. and Sorbi, A. (2015) Fault Movement Potential of Marzanabad Area, North Alborz, Iran. Open Journal of Geology, 5, 126-135. http://dx.doi.org/10.4236/ojg.2015.53012

[57] Arian, M. and Pourkermani, M. (2004) Tectonic Elements of South Flank in the East-Central Alborz Mountain. Journal of Sciences, Teacher Training University, 4, 359-368.

[58] Arian, M. and Qorashi, M. (2006) The Movement Potential Evaluation of the Major Quaternary Faults in Alborz-Central Iran Border Zone, from the East of Tehran to the East of Semnan. Journal of Geosciences, Geological Survey of Iran, 15, 184-188. 
[59] Poroohan, N., Pourkermani, M. and Arian, M. (2013) An Assessment of Relationship in F-Parameter and Paleostress Fields in Heterogeneous Lithologies: Roudbar Area (Northwest of Iran). Australian Journal of Basic \& Applied Sciences, 7, 933-942.

[60] Poroohan, N., Poukermani, M. and Arian, M. (2009) An Assessment on Correlations of Seismotectonic Parameters Preceding and Following Roudbar-Manjil Earthquake (Gilan, North of Iran). Australian Journal of Basic \& Applied Sciences, 3, 2643-2652.

[61] Farrokhnia, A.R., Pirasteh, S., Pourkermani, M. and Arian, M. (2011) Geo-Information Technology for Mass Wasting Hazard Zonation: Central-West Alborz-Iran. Disaster Advances, 4, 24-33.

[62] Khavari, R., Ghorashi, M. and Arian, M. (2009) Assessment of Relative Active Tectonics, South Central Alborz (North Iran). EGU General Assembly Conference Abstracts, 11, 1137.

[63] Sorbi, A., Arian, M. and Pourkermani, M. (2009) The Movement Potential Evaluation of the Major Quaternary Faults in Tehran Quadrangle. Journal of the Earth, 19, 176-182.

[64] Feizi, F. and Arian, M. (2006) The Classification of Thrust Fronts in the Alborz-Central Iran Border Zone from the East of Varamin to the East of Semnan. Journal of Sciences, 16, 75-87.

[65] Sadeghi, R., Saeedi, A., Arian, M., Ghorashi, M. and Solgi, A. (2015) Comparison of Strain Ellipsoid Shape in the South of Ardabil Range (NW), Based on the Results of the Magnetic Susceptibility Anisotropy and Paleostress Methods. Open Journal of Geology, 5, 611-622. http://dx.doi.org/10.4236/ojg.2015.59054

[66] Arian, M. and Pourkermani, M. (2004) Structural Significance of North Semnan and Attary Faults in Alborz-Central Iran Border Zone. Journal of Science, 14, 4551-4569.

[67] Arian, M. and Pourkermani, M. (2005) Cenozoic Diastrophism and Deformational Events in the Southern Flank of Central-East Alborz. Journal of Faculty Earth Sciences, 10, 43-51.

[68] Arian, M., Pourkermani, M., Qorashi, M. and Ghasemi, M.R. (2003) North Semnan Fault System and Its Role on Basin Division. 8th Symposium of Geological Society of Iran, Shahrood, 4-6 September 2003, 11-17.

[69] Pourkermani, M. and Arian, M. (2001) Structural Geomorphology of Northeastern Kurdistan. Journal of Humanities, 7, 37-48.

[70] Mardani, Z., Ghorashi, M. and Arian, M. (2011) Geomorphic Signatures of Active Tectonics in the Talaghan Rud, Shah Rud and Sefidrud Drainage Basins in Central Alborz, N Iran. Geosciences, 20, 159-166.

[71] Sorbi, A., Arian, M. and Pourkermani, M. (2011) The Application of Geomorphic Indices to the Assessment of Relative Tectonic Activity Levels in Tehran Quadrangle. Journal of the Earth, 6, 1-9.

[72] Khavari, R., Ghorashi, M., Arian, M. and Khosrotehrani, K. (2010) Geomorphic Signatures of Active Tectonics in the Karaj Drainage Basin in South Central Alborz, N, Iran. Geosciences, 19, 67-74.

[73] Javadi Mousavi, E. and Arian, M. (2015) Tectonic Geomorphology of Atrak River, NE Iran. Open Journal of Geology, 5, 106-114. http://dx.doi.org/10.4236/ojg.2015.53010

[74] Nouri, R., Jafari, M.R., Arian, M., Feizi, F. and Afzal, P. (2013) Correlation between Cu Mineralization and Major Faults Using Multifractal Modelling in the Tarom Area (NW Iran). Geologica Carpathica, 64, 409-416. http://dx.doi.org/10.2478/geoca-2013-0028

[75] Nouri, R., Jafari, M.R., Arian, M., Feizi, F. and Afzal, P. (2013) Prospection for Copper Mineralization with Contribution of Remote Sensing, Geochemical and Mineralographical Data in Abhar 1:100,000 Sheet, NW Iran. Archives of Mining Sciences, 58, 1071-1084. http://dx.doi.org/10.2478/amsc-2013-0074

[76] Nouri, R., Afzal, P., Arian, M., Jafari, M. and Feizi, F. (2013) Reconnaissance of Copper and Gold Mineralization Using Analytical Hierarchy Process in the Rudbar 1: 100,000 Map Sheet, Northwest Iran. Journal of Mining and Metallurgy, 49, 9-19.

[77] Farrokhnia, A.R., Pirasteh, S., Pradhan, B., Pourkermani, M. and Arian, M. (2011) A Recent Scenario of Mass Wasting and Its Impact on the Transportation in Alborz Mountains, Iran Using Geo-Information Technology. Arabian Journal of Geosciences, 4, 1337-1349. http://dx.doi.org/10.1007/s12517-010-0238-7

[78] Arian, M. and Nouri, R. (2015) Lineament Tectonics and Mineralization in Tarom Area, North Iran. Open Journal of Geology, 5, 115-124. http://dx.doi.org/10.4236/ojg.2015.53011

[79] Feizi, F. and Arian, M. (2011) The Role of Structural Controllers in Geneses of Copper Deposits in 1:50000 Map of Saiin Qaleh. Journal of Sciences, 21, 1-10.

[80] Arian, M., Qorashi, M. and Ahmadnia, A. (2003) Analysis of Behbahan Shear Zone. Iranian Journal of Geology, 1, $1-4$.

[81] Bahiraee, S, Arian, M., Qorashi, M. and Solgi, M. (2015) The Movement Potential Evaluation of the Mosha Fault (the West of Firoozkuh to the Shahrestanak). Geosciences, 24, 123-126. 
[82] Bagha, N., Ghorashi, M., Arian, M., Pourkermani, M. and Solgi, A. (2015) Neotectonic Analysis of Mosha-North Tehran Fault Zone, Based on Morphotectonic Features, Central Alborz, Northern Iran. Geosciences, 24, 41-52.

[83] Mosavi, E. and Arian, M. (2015) Neotectonics of Kashaf Rud River, NE Iran by Modified Index of Active Tectonics (MIAT). International Journal of Geosciences, 6, 776-794. http://dx.doi.org/10.4236/ijg.2015.67063

[84] Nouri, R. and Arian, M. (2015) Structural Control on the Distribution of Hydrothermal Alteration Zones and Mineralization in Dastjerdeh Area Based on Remote Sensing Data, NW Iran. Bulletin of the Georgian National Academy of Sciences, 9, 79-86.

[85] Sistanipour, A. and Arian, M. (2015) Geometric Analysis of Davaran Fault System, Central Iran. Open Journal of Geology, 5, 458-469. http://dx.doi.org/10.4236/ojg.2015.56043

[86] Nazemi, M., Ghorashi, M., Ghassemi, M.R. and Arian, M. (2015) Morphotectonics Features of Alluvial Fans Associated with Active Tectonics (Shotori Mountains, East of Tabas-Central Iran). Geosciences, 24, 91-100.

[87] Alizadeh, H. and Arian, M. (2015) Rule of Structural Factors in Formation of Porphyry Copper Deposits in South Western Part of Kerman Area, Iran. Open Journal of Geology, 5, 489-498. http://dx.doi.org/10.4236/ojg.2015.57045

[88] Javadi Mosavi, E. and Arian, M. (2015) Neotectonics of Tabas Area, Central Iran by Index of Active Tectonics (IAT). Open Journal of Geology, 5, 209-223. http://dx.doi.org/10.4236/ojg.2015.54019

[89] Jamalian Daryani, N., Arian, M. and Rashidnezhad Omran, N. (2015) Tectonics and Mineralization of Copper in the Ardestan-Kahang area, Central Iran by Remote Sensing. Open Journal of Geology, 5, 188-196. http://dx.doi.org/10.4236/ojg.2015.54017

[90] Arian, M. and Pourkermani, M. (2001) Rivers Morphology and Active Tectonic (Reviewing the Current Status of Ghezel Ozon River in the Province of Zanjan). 5th Conference of Geological Society of Iran, Tehran, 28-30 August 2001, 556.

[91] Eshghi, Z., Arian, M. and Pourkermani, M. (2012) Structural Investigation on the Lak Mining Area (Bueen Zahra) Based on Remote Sensing, Used for Its Mineralization. Journal of the Earth, 6, 145-155.

[92] Arian, M., Toudeshki, V.H. and Noroozpour, H. (2011) Active Tectonics of Qezel Ozan River Basin, NW Iran. Journal of Applied Environmental and Biological Sciences, 1, 291-295.

[93] Alizadeh, H., Arian, M., Lotfi, M., Ghorashi, M. and Ghorbani, M. (2015) Determination of Porphyry Copper Deposit Locations Using Photo Lineament Factor in Northern Parts of the Dehaj-Sardoiyeh Belt. Geosciences, 24, $247-252$.

[94] Housini Toudeshki, V., Pourkermani, M., Arian, M. and Khosrotehrani, K.H. (2011) Influence of Structures on the Ghezel Ozan River. Geosciences, 21, 55-60.

[95] Housini Toudeshki, V. and Arian, M. (2011) Morphotectonic Analysis in the Ghezel Ozan River Basin, NW Iran. Journal of Geography and Geology, 3, 258-260. http://dx.doi.org/10.5539/jgg.v3n1p258

[96] Arian, M. (2015) Seismotectonic-Geologic Hazards Zoning of Iran. Earth Sciences Research Journal, 19, 7-13. http://dx.doi.org/10.15446/esrj.v19n1.40664

[97] Arian, M., Pourkermani, M., Sistanipour, A. and Noroozpour, H. (2011) Kinematic Significance of Fold- and FaultRelated Fracture Systems in the Rafsanjan’s Northeast Highlands (Central Iran). Journal of Basic and Applied Scientific Research, 1, 3398-3406.

[98] Arian, M., Pourkermani, M., Sistanipour, A. and Noroozpour, H. (2011) Seismicity and Fault Segmentation of BafqBaghin Fault System (Central Iran). Journal of Applied Environmental and Biological Sciences, 1, 382-396.

[99] Javadi Mosavi, E., Arian, M., Ghorashi, M. and Nazemi, M. (2012) Measurements of Geomorphic Indices in Tabas Area. Journal of the Earth, 7, 213-225.

[100] Arian, M. (2010) Earthquake-Fault Hazard Investigations in the Kerman Quadrangle. Journal of Sciences, 19, $176-182$.

[101] Cox, R.T. (1994) Analysis of Drainage Basin Symmetry as a Rapid Technique to Identify Areas of Possible Quaternary Tilt Block Tectonics: An Example from the Mississippi Embayment. Geological Society American Bulletin, 106, 571581. http://dx.doi.org/10.1130/0016-7606(1994)106<0571:AODBSA>2.3.CO;2 